\title{
Kvalita vyjadrovania zákonodarcu v kontexte právnej zodpovednosti podl'a zákona o obecnom zriadení
}

Lukáš Tomaš *

DOI: https://doi.org/10.24040/sap.2020.7.4.384-393

\begin{abstract}
Abstrakt:
TOMAŠ, Lukáš: Kvalita vyjadrovania zákonodarcu $v$ kontexte právnej zodpovednosti podla zákona o obecnom zriadení. Zámerom predkladaného článku je rozbor niektorých sporných okruhov správnych deliktov podl’a $\S 27 \mathrm{~b}$ zákona č. 369/1990 Zb. o obecnom zriadení, a to najmä v kontexte preskúmania dôslednosti (exaktnosti, presnosti) vyjadrovania zákonodarcu v dikcii tohto ustanovenia. Autor si nedáva za ciel' predstavit' problematiku komplexným alebo popisným spôsobom. Pozornost' sa koncentruje na teoretickú stránku úpravy a problémové aspekty. V prvom rade skúma, $\mathrm{v}$ akom zmysle treba interpretovat' označenie normatívneho právneho aktu „nariadenie“. Zamýšla sa, či treba výklad redukovat' na „všeobecne záväzné nariadenie obce“, alebo či môže íst' aj o „nariadenie vlády Slovenskej republiky“. V druhej časti príspevku uvažuje o tom, či možno vybrané správne delikty podl'a tohto ustanovenia spáchat' v jednočinnom súbehu. Naostatok formuluje názory nato, či viacnásobné a opakované porušenie povinností má predstavovat' recidívu alebo súbeh.
\end{abstract}

\section{Kl'účové slová:}

právny jazyk, obec, administratívna zodpovednost', všeobecne záväzné nariadenie, súbeh, recidíva

\section{The Quality of Legislator's Expression in the Context of Legal Liability according to the Act of Municipal Establishment}

\begin{abstract}
:
TOMAŠ, Lukáš: The quality of legislator's expression in the context of legal liability according to the act of municipal establishment. The intention of the presented article is the analysis of some disputable areas of administrative torts according to $\S 27 \mathrm{~b}$ of the Act No. 369/1990 Coll. of municipial establishment especially in the context of examining the exactness of the legislator's statement in the verbalisation of this statute. The author does not aim to present the issue in a comprehensive or descriptive way. Attention is focused on the theoretical side of the adjustment and problem aspects. It first examines the meaning in which the designation of a legislative act 'regulation' must be interpreted. It considers whether the interpretation should be reduced to a "generally binding regulation of the municipality", or whether it may also be a "regulation of the Government of the Slovak Republic". In the second part of
\end{abstract}

* Mgr. Lukáš Tomaš, Univerzita Pavla Jozefa Šafárika v Košiciach, Právnická fakulta, Ústav teórie práva Gustava Radbrucha, interný doktorand. 
the paper, he considers whether selected administrative offenses under this provision can be committed in a single act. The remainder formulates opinions as to whether multiple and repeated breaches of duty should constitute recidivism or overlap.

\section{Key words:}

Legal language, municipality, administrative liability, generally binding regulation, concurrence, recidivism.

\section{I. Úvod}

So zodpovednost'ou sa stretneme vo všetkých spoločenských vzt'ahoch. ${ }^{1}$ Problematika zodpovednosti (zodpovednostných vzt'ahov) patrí nielen k najdôležitejším, ale aj k najzložitejším vo všetkých spoločenských vedách, právnu vedu nevynímajúc. ${ }^{2}$ Zložitost' zodpovednostných okruhov sa osobitne významne prejavuje a dostatočným spôsobom zhodnocuje vo vede a normotvorbe administratívneho práva. Uvedené podčiarkuje (dokladuje, objektivizuje) viacero faktorov.

Prvou skutočnost’ou môže byt' vecne neúplná úprava správneho trestania. Právna úprava deliktného práva verejnej správy je medzerovitá, ${ }^{3} \mathrm{v}$ určitých aspektoch nezohl'adňujúca právo na spravodlivý proces. Táto skutočnost' v správnej súdnej praxi dlhodobo odôvodňuje využívanie analógie trestného práva v právno-aplikačných reáliách správneho trestania.

Iným nedostatkom môže byt' nerešpektovanie legislatívnych pravidiel v procese novelizácie administratívno-procesných predpisov. Zákonodarca sa $\mathrm{v}$ tak významných otázkach, ako je verejnoprávne trestanie, neštíti nepriamych novelizácií. Hodno spomenút' napríklad nepriamu novelizáciu ${ }^{4}$ relevantných ustanovení osobitných administratívnych predpisov požadujúca aplikáciu základných zásad trestného konania v kontexte právno-realizačných postupov pri správnom trestaní [§ 195 písm. c) Správneho súdneho poriadku]. ${ }^{5}$

1 FÁBRY, B. - KASINEC, R. - TURČAN, M.: Teória práva. Bratislava : Wolters Kluwer, 2017, s. 218.

2 Podobne KANÁRIK, I.: Právna zodpovednost'. In: BRÖSTL, A. a kol.: Teória práva. Plzeň : Aleš Čeněk, 2013, s. 146.

3 Pozri napr. SREBALOVÁ, M.: Limity aplikácie zásad správneho trestania v praxi. In: Přestupky a rrízení o nich z pohledu teorie a praxe. Praha : Policejní akademie ČR, 2014, s. 236 a nasl.; FEČÍK, M. - FILOVÁ, A.: Komentár k § 194 Správneho súdneho poriadku. In: BARICOVÁ, J. - FEČÍK, M. - ŠTEVČEK, M. - FILOVÁ, A. a kol.: Správny súdny poriadok. Komentár. Bratislava : C. H. Beck, 2018, s. 976-977.

4 SEMAN, T.: Vplyv ustanovení o správnej žalobe vo veciach správneho trestania (§ 194 $\S 198$ zákona č. 162/2015 Z. z. Správny súdny poriadok, v znení neskorších predpisov) na administratívne konanie vo veciach správneho trestania. In: FRUMAROVÁ, K. (ed.): Správní soudnictví - 15 let existence soudního řádu správního vs. prvotní zkušenosti s aplikací nového správneho súdneho poriadku. Olomouc: Iuridicum Olomoucense, o.p.s., 2018, s. 287.

5 Podl’a $§ 195$ písm. c) Správneho súdneho poriadku správny súd nie je vo veciach správneho trestania viazaný rozsahom a dôvodmi žaloby, ak ide o základné zásady trestného konania podl'a Trestného poriadku, ktoré je potrebné použit’ na správne trestanie. 
Osobitým znakom právnej úpravy osobitnej časti hmotnoprávnych aspektov administratívneho trestania (zjednodušene povedané, skutkových podstát správnych deliktov) je absencia kodifikácie. Uvedená matéria je regulovaná množstvom právnych predpisov, a to tak všeobecnej, ako aj osobitnej časti správneho práva. Jedným z takýchto predpisov je aj zákon č. 369/1990 Zb. o obecnom zriadení.

Ciel'om príspevku je analýza vybraných aspektov deliktuálnej úpravy obsiahnutej v zákone č. 369/1990 Zb. o obecnom zriadení, najmä so zretel'om na dôslednost' (exaktnost', presnost') vyjadrovania zákonodarcu. Autor si nedáva za ciel' komplexne alebo deskriptívne predstavit' problematiku. Pozornost' sa koncentruje na teoretickú stránku úpravy (všeobecná právna teória, teória administratívneho práva, teória trestného práva) a problémové aspekty. Základnou hypotézou vedeckého výskumu je konštatovanie, že dikcia § 27b zákona č. 369/1990 Zb. o obecnom zriadení vyžaduje legislatívno-technické precizácie. Ak sa uvedená hypotéza potvrdí, ambíciou práce je formulovat' návrhy de lege ferenda.

Na účel naplnenia ciel’a a overenia hypotézy sa využívali spôsoby vedeckej práce, pri ktorých sa uplatňuje tvorivá vedecká činnost', teda metódy právneho výskumu. ${ }^{6}$ V tomto zmysle sa aplikovali najmä metóda analytická, metóda syntetická, metóda komparatívna.

\section{II. Úvahy nad dikciou § 27b zákona č. 369/1990 Zb. o obecnom zriadení}

\section{II.1 Úvodné poznámky}

Úprava administratívno-právnej zodpovednosti sa v zákone č. 369/1990 Zb. o obecnom zriadení koncentruje do jediného ustanovenia $\S 27$ b. Toto ustanovenie bolo zavedené novelou č. 125/2015 Z. z., ktorá nadobudla účinnost' 1. júla 2015.

Napriek pomerne krátkemu obdobiu účinnosti bolo analyzované ustanovenie už novelizované (novelou č. 70/2018 Z. z. účinnou od 1. apríla 2018). Som názoru, že túto novelu by mala nasledovat' d'alšia, obsahovo podrobnejšia legislatívna zmena. Táto by sa zo systematických dôvodov mala dotknút aj súvisiacich ustanovení zákona č. 369/1990 Zb. o obecnom zriadení. Domnievam sa totiž, že § 27b zákona č. 369/1990 Zb. o obecnom zriadení obsahuje viacero problematických miest.

\section{II.2 Nie je nariadenie ako nariadenie}

Prvým problémom je problematické znenie $\S 27 \mathrm{~b}$ ods. 1 písm. a) zákona č. 369/1990 Zb. o obecnom zriadení. Podl'a doslovnej dikcie sa správneho deliktu dopustí právnická osoba alebo fyzická osoba - podnikatel', ktorá poruší „nariadenie“. Na prvý pohl'ad sa uvedená legislatívna konštrukcia javí jednoznačná, interpretačne a aplikačne nesporná. Zdá sa, že „nariadením“ sa myslí „,v̌̌eobecne záväzné nariadenie obce“. To podporuje aj znenie § 2a ods. 2 písm. f) zákona č. 369/1990 Zb. o obecnom zriadení, ktoré zavádza legislatívnu skratku „,nariadenie“ vo vzt’ahu k „,v̌̌eobecne záväznému nariadeniu“.

6 HUNGR, P. - DOBROVIČOVÁ, G.: Sociológia práva. Rektorát Univerzity P. J. Šafárika v Košiciach, 1990, s. 57. 
Po dôslednom preskúmaní normatívnej úpravy, zohl'adniac systémovú súvislost', sa prvotná istota stráca. Zákonodarca totožnou skratkou ,nariadenie“ označuje v normatívnom texte nielen všeobecne záväzné nariadenie obce, ale aj nariadenie vlády SR v súvislosti s výkonom pôsobnosti vlády SR vo vztahu k obecnému názvosloviu a modifikáciám územného základu obce (pozri § 1a ods. 2 , § 2 ods. 3 , § 2aa ods. 1 zákona č. 369/1990 Zb. o obecnom zriadení). Zákon teda používa celkom totožné označenie pre dva druhy normatívnych právnych aktov, ktoré sa odlišujú (i) z hl'adiska právomoci a kompetencie vydávajúceho orgánu, (ii) z hl'adiska stupňa právnej sily, a pokial' ide o originárne všeobecne záväzné nariadenia, aj (iii) z hl’adiska mocenského charakteru orgánu, ktorý právny predpis vydáva. ${ }^{7}$ Tento nedostatok treba de lege lata konvalidovat' prísne zužujúcim (reštriktívnym) výkladom $\S 27$ b ods. 1 písm. a) zákona č. 369/1990 Zb. o obecnom zriadení. Nariadením v kontexte tohto ustanovenia treba rozumiet' výlučne všeobecne záväzné nariadenie obce. Obec nemôže sankcionovat' porušenie nariadenia vlády SR (napr. v súvislosti so zmenou názvu obce, rozdelením, zrušením, rozdelením obce, zlúčením obcí alebo pričlenením nefunkčnej obce k susediacej obci).

V aplikačnej praxi sa vyskytli úvahy, či by na základe tohto ustanovenia nebolo možné sankcionovat' porušovanie všeobecne záväzných nariadení samosprávneho kraja. Takéto úvahy treba odmietnut' využitím formálno-systematického výkladu. „Nariadením“ v zmysle § 27b ods. 1 písm. a) zákona č. 369/1990 Zb. o obecnom zriadení v kontexte $\mathrm{s} \S 2 \mathrm{a}$ ods. 2 písm. f) tohto zákona, ktoré zavádza legislatívnu skratku „nariadenie“ vo vzt’ahu k „,šeobecne záväznému nariadeniu obce“, nemožno rozumiet' všeobecne záväzné nariadenie samosprávneho kraja.

Domnievam sa, že používanie označenia „nariadenie“ vo vzt’ahu k odlišným druhom prameňov práva tak, ako sa to zákonodarcovi práve hodí, koliduje so základným atribútom presnosti právneho jazyka. M. Tóthová vyslovuje, že právny jazyk má povahu odborného jazyka, pre ktorý je charakteristické, že každé slovo v ňom musí mat' účelovo presne vymedzený význam, aby mohlo byt’ presným nástrojom regulácie. ${ }^{8}$ Ústavný súd SR, do istej miery paradoxne práve k posudzovaniu ústavnosti ustanovení zákona č. 369/1990 Zb. o obecnom zriadení, vyriekol: „Ústavný súd podčiarkuje význam právneho pojmoslovia a právnej terminológie pri tvorbe právnych predpisov. Je toho názoru, že základným princípom právneho jazyka je jednoznačné, nespochybnitel'né vyjadrovanie vecí, skutočností, javov a procesov, ktorý kladie vel'ký dôraz na použitie takých právnych termínov, aby tieto označovali iba jeden právny pojem, ktorému by nemal chýbat' reálny obsah, t. j. mal by byt' definovaný, ak sa má v právnych vzt’ahoch aplikovat." "' Uvedené závery právnej teórie a doktríny najvyšších súdnych autorít nie sú v normatívnej dikcii zákona č. 369/1990 Zb. o obecnom zriadení dôsledne rešpektované.

Svojvol'né používanie totožného termínu na dve odlišné formy práva neprospieva ani zrozumitel'nosti právneho jazyka. Jazyk právneho predpisu by mal byt' zrozumi-

7 Pozri bližšie DOBROVIČOVÁ, G.: Pramene práva. In: BRÖSTL, A. a kol.: c. d. v pozn. pod čiarou č. 2, s. 46-47.

8 TÓTHOVÁ, M.: Interpretácia práva a právny jazyk. In: Dny práva - 2010 - Days of Law : sborník př́spěvků : 4.ročník mezinárodní konference. Brno : Masarykova univerzita, 2010, s. 2994.

9 Nález Ústavného súdu Slovenskej republiky sp. zn. PL. ÚS 19/05 zo dňa 30. apríla 2008. 
tel'ný pre čo najviac občanov, ktorí sú adresátom noriem v ňom obsiahnutých. ${ }^{10}$ Ťažko možno očakávat', že priemerný recipient obecnej normotvorby bude k uvedenému problému pristupovat kombináciou viacerých druhov výkladu práva. Táto úprava nie je všeobecne zrozumitel'ná.

Problémom môže byt' i narušenie právnej istoty adresátov verejnomocenskej regulácie v súvislosti s prejednávaním správnych deliktov. Presnost' vyjadrovania tvorcu práva by mala byt' osobitne v sankčnom práve absolútnou prioritou.

Domnievam sa, že de lege ferenda by bolo potrebné označenie „nariadenie“ používat' v dikcii zákona č. 369/1990 Zb. o obecnom zriadení vo vzt’ahu k jedinému druhu prameňov práva. Nariadenie vlády SR by sa malo označovat' legislatívnou skratkou „nariadenie“. Túto legislatívnu skratku by bolo potrebné uviest' spôsobom zodpovedajúcim legislatívnym pravidlám. Všeobecne záväzné nariadenie obce by sa malo legislatívne skracovat' ako „,v̌eobecne záväzné nariadenie“. I používanie tejto legislatívnej skratky by malo konvenovat’ legislatívnym pravidlám.

\section{II.3 Správne delikty podl’a zákona č. 369/1990 Zb. o obecnom zriadení a vylúčenie jednočinného súbehu}

Zákon č. 369/1990 Zb. o obecnom zriadení v § 27b ods. 1 písm. a) nešpecifikuje kategóriu všeobecne záväzných nariadení, ktoré možno porušit'. Všeobecne záväzné nariadenia nemožno interpretačne redukovat' na určitú kategóriu obecnej normotvorby. Porušit' možno všeobecne záväzné nariadenie vydané vo veciach územnej samosprávy (pôvodné všeobecne záväzné nariadenie) i všeobecne záväzné nariadenie vydané pri prenesenom výkone štátnej správy obcou (odvodené všeobecne záväzné nariadenie). ${ }^{11}$ Môže íst' o všeobecne záväzné nariadenie, ktoré je obec povinná vydat' (obligatórne všeobecne záväzné nariadenie) i všeobecne záväzné nariadenie, ktoré obec môže vydat' na základe vlastného samosprávneho uváženia (fakultatívne všeobecne záväzné nariadenie).

Aplikačný problém môže nastat' v prípade porušenia pravidiel pre udržovanie čistoty v obci. Nedodržovanie čistoty na uživanom pozemku alebo na inej nehnutel'nosti v príčinnom vzt'ahu s narušením vzhl'adu alebo prostredia obce, ako aj znečistenie verejného priestranstva, osobitne postihuje písm. b) § 27b ods. 1 zákona č. 369/1990 Zb. o obecnom zriadení. Na druhej strane je obec povinná všeobecne záväzným nariadením ustanovit' pravidlá na udržiavanie čistoty v obci na základe splnomocňujúcej normy obsiahnutej v $\S 4$ ods. 5 písm. a) druhý bod zákona č. 369/1990 Zb. o obecnom zriadení. Porušenie všeobecne záväzného nariadenia treba následne sankcionovat' podl'a $\S 27$ b ods. 1 písm. a) zákona č. 369/1990 Zb. o obecnom zriadení.

V konkrétnom prípade by mohlo dôjst' súčasne $\mathrm{k}$

- porušeniu VZN, ktoré obsahuje pravidlá na udržiavanie čistoty v obci [skutková podstata správneho deliktu podla $§ 27 \mathrm{~b}$ ods. 1 písm. a) zákona č. 369/1990 Zb. o obecnom zriadení] a

10 FÁBRY, B. - KASINEC, R. - TURČAN, M.: c. d. v pozn. pod čiarou č. 1, s. 305.

$11 \mathrm{~K}$ diferenciácii všeobecne záväzných nariadení obce napr. TEKELI, J.: Všeobecne záväzné nariadenia. In: TEKELI, J. - TOMAŠ, L.: Všeobecne záväzné nariadenia v školstve. Bratislava : Josef Raabe, 2018, s. 12 a nasl. 
- neudržiavaniu čistoty na užívanom pozemku alebo na inej nehnutel'nosti v príčinnom vzt’ahu s narušením vzhl'adu alebo prostredia obce, prípadne k znečisteniu verejného priestranstva [skutková podstata správneho deliktu podla $\S 27 \mathrm{~b}$ ods. 1 písm. b) zákona č. 369/1990 Zb. o obecnom zriadení].

V praxi by bolo možné uvažovat' o jednočinnom súbehu správnych deliktov podla písm. a) a písm. b) tohto ustanovenia. Som názoru, že jednočinný súbeh správnych deliktov je vylúčený. Dôvodom vylúčenia jednočinného súbehu je pomer špeciality (lex specialis derogat legi generali) medzi oboma ustanoveniami. Ustanovenie $\S 27 \mathrm{~b}$ ods. 1 písm. b) zákona č. 369/1990 Zb. o obecnom zriadení má zúžený rozsah v pomere $\mathrm{k}$ abstraktnejšej skutkovej podstate obsiahnutej v písm. a) tohto ustanovenia. Zákonné znaky všeobecnejšej skutkovej podstaty sú v konkrétnejšej skutkovej podstate konkretizované a doplnené. ${ }^{12}$ Povedané inak, porušením všeobecne záväzného nariadenia podl’a $\S 27 b$ ods. 1 písm. a) zákona č. 369/1990 Zb. o obecnom zriadení môže byt' aj konanie, ktoré nenapíña znaky skutkovej podstaty normovanej v písm. b) tohto ustanovenia. V takom prípade je nevyhnutné vyvodzovat' správno-právnu zodpovednost' podla písm. a) tohto ustanovenia. Ak konanie naplńa skutkovú podstatu písm. a) aj písm. b) tohto ustanovenia, možno stíhat' len správny delikt uvedený v písm. b).

Vylúčenie jednočinného súbehu treba $\mathrm{v}$ analyzovanej súvislosti dovodit’ len aplikáciou teoretických záverov vedy trestného práva hmotného. Nevyplývajú z predpisov správneho práva a administratívno-právna doktrína sa im venuje len okrajovo. Je na mieste, aby zákonodarca $\mathrm{v}$ procese zhodnocovania efektívnosti právnej úpravy zvážil normatívne upravenie vzt’ahu traktovaných skutkových podstát.

\section{II.4 Viacnásobné a opakované porušenie povinností - recidíva alebo súbeh?}

V § 27b ods. 3 zákona č. 369/1990 Zb. o obecnom zriadení zákonodarca taxatívnym a pozitívnym spôsobom ustanovuje okolnosti, na ktoré je povinná obec prihliadnut' pri určovaní výmery správnej sankcie za správne delikty podla tohto ustanovenia. Pri ukladaní pokuty treba zohl'adnit' okrem iného (i) porušenie viacerých povinností a (ii) opakované porušenie povinností.

Porušenie viacerých povinností ako následok správneho deliktu sa v právnej teórii a súdnej praxi kvalifikuje ako prit’ažujúca okolnost', hoci právna úprava zákona č. 369/1990 Zb. o obecnom zriadení kategóriu prit’ǎujúcich okolností nepozná. Obdobne aj opakované porušenie povinností sa poníma ako pritažujúca okolnost'. Ak bude povinnost' porušená opakovane, prípadne dôjde k porušeniu viacerých povinností, môže obec uvažovat' o uložení pokuty, ktorá sa blíži k hornej hranici sadzby správnej sankcie (6 638 eur). Obec nemôže prekročit' túto hranicu.

Nejasný ostáva vzt'ah opakovaného porušenia povinností a porušenia viacerých povinností. V samosprávnej teórii a praxi sa naň vyskytli viaceré názory.

Niektorí autori ${ }^{13}$ sú názoru, že opakovaným porušením (tých istých alebo odlišných) povinností treba rozumiet' recidívu, čiže prípad opätovného porušenia po-

12 JELÍNEK, J.: Souběh trestních činů. In: NOVOTNÝ, O. - DOLENSKÝ, J. - JELÍNEK, J. VANDUCHOVÁ, M.: Trestní právo hmotné - I. Obecná část. Praha : Aspi Publishing, 2003, s. 250.

13 KOŠIČIAROVÁ, S.: Zákon o obecnom zriadení. Komentár. Bratislava : Eurokódex, 2018, s. 179. 
vinnosti potom, čo bola osoba za správny delikt už postihnutá. Prit’ažujúca okolnost' spočívajúca $\mathrm{v}$ porušení viacerých povinností sa potom aplikuje v prípade, ak dôjde k porušeniu viacerých (tých istých alebo odlišných) povinností skôr, než je o ktoromkol’vek porušení právoplatne rozhodnuté. Tieto názory podporuje aj súdna prax (porovnaj napr. rozsudok Krajského súdu Trnava sp. zn. 43Sa/11/2016 zo dňa 2. októbra 2017).

Iný záver môže priniest' komparatívny pohl'ad na vec. Trestnoprávna regulácia, ktorú treba na základe ustálených záverov rozhodovacej činnosti súdov analogicky používat' aj v správnom trestaní, rozumie opakovaním trestného činu prípad spáchania toho istého deliktu viackrát skôr, než dôjde k vyvodeniu trestnej zodpovednosti. Podl'a $§ 122$ ods. 9 Trestného zákona trestný čin je spáchaný opakovane, ak páchatel' postupne spáchal viac rovnakých trestných činov opakovanými samostatnými činmi, medzi ktorými nie je žiadna objektívna alebo subjektívna súvislost', pričom trestnost' každého z nich sa posudzuje samostatne. $V$ uvedenom ponímaní sa zdôrazňuje, že opakovanie trestnej činnosti nie je recidívou, ale viacčinným rovnorodým súbehom. ${ }^{14}$ Kvalifikovanie „opakovaného porušenia povinnosti“ podl’a $\S 27 \mathrm{~b}$ ods. 3 zákona č. 369/1990 Zb. o obecnom zriadení ako recidívy s uvedeným záverom koliduje.

Alternatívnym výkladom $\S 27 b$ ods. 3 zákona č. 369/1990 Zb. o obecnom zriadení by porušením viacerých povinností bolo možné rozumiet' porušenie dvoch alebo viacerých odlišných povinností. Opakovaným porušením povinností by bolo treba chápat' porušenie totožnej povinnosti aspoň dvakrát. $V$ oboch prípadoch by šlo o súbeh - v prvom prípade rôznorodý, $\mathrm{v}$ druhom prípade rovnorodý. Recidíva by sa na účely postihovania analyzovaných správnych deliktov nepovažovala za prit’ažujúcu okolnost'.

Domnievam sa, že na účel eliminovania možných dvojakých výkladových prístupov k dikcii § $27 b$ ods. 3 zákona č. 369/1990 Zb. o obecnom zriadení by bolo na mieste, aby zákonodarca jednoznačne vymedzil vzt’ah opakovaného porušenia povinností a porušenia viacerých povinností aj v normatívnom texte. Navrhovaná zmena by $\mathrm{v}$ rovine právneho vedomia de lege ferenda prispela i $\mathrm{k}$ zabezpečeniu vyššej miery právnej istoty adresátov verejnej správy.

\section{Záver}

Ciel’om predkladaného článku bol rozbor niektorých právno-teoretických súvislostí úpravy správnych deliktov podl'a $§ 27 \mathrm{~b}$ zákona č. 369/1990 Zb. o obecnom zriadení. Bez nároku na úplné zvládnutie problematiky som sa pokúsil predstavit' problémové aspekty, a to najmä z pohl'adu kvality vyjadrovania zákonodarcu.

Základnou hypotézou vedeckého výskumu bolo konštatovanie, že dikcia $\S 27 \mathrm{~b}$ zákona č. 369/1990 Zb. o obecnom zriadení bude potrebné do budúcna pozmenit'.

14 MADLIAK, J.: Trestný čin. In: MADLIAK, J. a kol.: Trestné právo hmotné I. Všeobecná čast'. Košice : Univerzita Pavla Jozefa Šafárika v Košiciach, 2010, s. 121. K diferenciácii súbehu a recidívy FERENČÍKOVÁ, S.: Vybrané ustanovenia všeobecnej časti Trestného zákona modifikujúce trestné sadzby trestu odňatia slobody. In: Pojem a účel sankcií v slovenskom trestnom práve : zborník vedeckých prác. Košice : Vysoká škola bezpečnostného manažérstva v Košiciach, 2011, s. 12-20; FERENČ́́KOVÁ, S. Analysis and evaluation of the legal regulation, de lege lata, concerning the imposition of a custodial sentence in the Slovak Republic. In: Social'no-političeskije nauki. roč. 10, č. 3, 2020. (s. 95-114). 
Táto hypotéza sa potvrdila. Platná právna úprava vykazuje viacero nedostatkov a nejednoznačností. V nadväznosti nato sa vytvoril priestor pre úvahy o návrhoch na skvalitnenie právnej úpravy.

Prvým nedostatkom je používanie rovnakých pomenovaní pre rôzne druhy prameňov práva. Zákon používa označenie „nariadenie“ vo vzt’ahu k nariadeniu vlády SR i všeobecne záväznému nariadeniu obce. Uvedené koliduje s požiadavkou presnosti a všeobecnej zrozumitel'nosti právneho jazyka, ako aj s právnou istotou adresátov právnej regulácie $\mathrm{v}$ súvislosti s prejednávaním správnych deliktov. De lege ferenda by bolo potrebné oba druhy prameňov práva dôsledne odlíšit', a to zavedením dvoch rôznych legislatívnych skratiek.

Druhý okruh výskumu predstavovalo hl'adanie uspokojivej odpovede na otázku, či porušenie povinnosti ohl'adom dodržovania čistoty v obci môže založit' jednočinný súbeh správnych deliktov podl'a $\S 27 \mathrm{~b}$ ods. 1 písm. a) a písm. b) tohto ustanovenia. Primeraným použitím trestnoprávnej teórie treba vzt’ah písm. a) a písm. b) tohto ustanovenia kvalifikovat' ako pomer špeciality. Dôsledkom je vylúčenie jednočinného súbehu. Takýto prístup je však pomerne t’ažkopádny a v reáliách slovenských obcí pravdepodobne nepredstavitel'ný. Vzt’ah medzi § $27 \mathrm{~b}$ ods. 1 písm. a) a písm. b) zákona č. 369/1990 Zb. o obecnom zriadení by mal objektivizovat' zákonodarca.

Ostatný problém spočíva v nejasnom vzt'ahu opakovaného porušenia povinností a porušenia viacerých povinností podl’a § 27b ods. 3 zákona č. 369/1990 Zb. o obecnom zriadení. Predovšetkým nie je zrejmé, či prit’ažujúca okolnost' „opakované porušenie povinností “ má implikovat' recidívu alebo konkurenciu. Doterajšia administratívnoprávna doktrína i správna súdna prax sa prikláňala skôr k recidíve. Analogickou aplikáciou $\S 122$ ods. 9 Trestného zákona by bolo možné uvažovat’ o konkurencii (súbehu). I uvedenej otázke by mala budúca právna úprava venovat' náležitejšiu pozornost'.

\section{Literatúra:}

- BARICOVÁ, Jana-FEČÍK, Marián-ŠTEVČEK, Marek - FILOVÁ, Anita a kol.: Správny súdny poriadok. Komentár. Bratislava : C. H. Beck, 2018, 1824 s. ISBN 978-80-7400-678-4.

- BREICHOVÁ LAPČÁKOVÁ, Marta: Právna zodpovednost' ako druh spoločenskej zodpovednosti. In: Postavenie verejných funkcionárov v právnom poriadku Slovenskej republiky : Zbornik vedeckých prác. Košice : Univerzita Pavla Jozefa Šafárika v Košiciach, 2012. (s. 123-137). ISBN 9788070979426.

- BRÖSTL, Alexander a kol.: Teória práva. Plzeň : Aleš Čeněk, 2013, 199 s. ISBN 978-80-7380-425-1.

- FÁBRY, Branislav - KASINEC, Rudolf - TURČAN, Martin: Teória práva. Bratislava : Wolters Kluwer, 2017, 356 s. ISBN 978-80-8168-595-8.

- FERENČÍKOVÁ, Simona: Analysis and evaluation of the legal regulation, de lege lata, concerning the imposition of a custodial sentence in the Slovak Republic. In: Socialno-političeskije nauki. roč. 10, č. 3, 2020. (s. 95-114). ISSN 2223-0092.

- FERENČ́́KOVÁ, Simona: Vybrané ustanovenia všeobecnej časti Trestného zákona modifikujúce trestné sadzby trestu odňatia slobody. In: Pojem a účel sankcií $v$ slovenskom trestnom práve : zbornik vedeckých prác. Košice : Vysoká škola bezpečnostného manažérstva v Košiciach, 2011. (s. 12-20). ISBN 9788089282739. 
- FERENČÍKOVÁ, Simona: Základné zásady trestnej zodpovednosti. In: Zeszyty Naukowe Universytetu Rzeszowskiego : seria prawnicza. vol. 94, č. 19, 2016. (s. 36-49). ISSN 1730-3508.

- HUNGR, Pavel - DOBROVIČOVÁ, Gabriela: Sociológia práva. Rektorát Univerzity P. J. Šafárika v Košiciach, 1990, s. 57. ISBN 80-7097-090-1.

- KOŠIČIAROVÁ, Soňa: Zákon o obecnom zriadení. Komentár. Bratislava : Eurokódex, 2018, 198 s. ISBN 978-80-8155-079-9.

- MADLIAK, Jozef a kol.: Trestné právo hmotné I. Všeobecná čast'. Košice : Univerzita Pavla Jozefa Šafárika v Košiciach, 2010, s. 456 s. ISBN 978-80-7097825-2. ISBN 80-86395-73-1.

- MICHALOV, Lukáš: Materiálny korektív a jeho aplikácia. In: Princípy a zásady $v$ trestnom práve : zborník vedeckých prác z Medzinárodnej vedeckej konferencie s názvom Pocta docentovi Rašlovi na tému Princípy a zásady trestného práva : 16. - 17. september 2014, Košice. Košice : Univerzita Pavla Jozefa Šafárika v Košiciach, 2014. (s. 265 - 274). ISBN 978-80-8152-223-9.

- NOVOTNÝ, Oto-DOLENSKÝ, Adolf-JELÍNEK, Jiří-VANDUCHOVÁ, Marie: Trestní právo hmotné - I. Obecná část. Praha : Aspi Publishing, 2003, 436 s.

- SEMAN, Tibor: Vplyv ustanovení o správnej žalobe vo veciach správneho trestania ( $\$ 194-\S 198$ zákona č. 162/2015 Z. z. Správny súdny poriadok, v znení neskorších predpisov) na administratívne konanie vo veciach správneho trestania. In: FRUMAROVÁ, Kateřina (ed.): Správní soudnictví - 15 let existence soudního rádu správního vs. prvotní zkušenosti s aplikací nového správneho súdneho poriadku. Olomouc: Iuridicum Olomoucense, o.p.s., 2018 (s. 273 - 295). ISBN 978-80-88266-25-9.

- SREBALOVÁ, Mária: Limity aplikácie zásad správneho trestania v praxi. In: Přestupky a ř́zení o nich z pohledu teorie a praxe. Praha : Policejní akademie ČR, 2014 (s. 235-244). ISBN 978-80-7251-408-3.

- TEKELI, Jozef - TOMAŠ, Lukáš: Všeobecne záväzné nariadenia v školstve. Bratislava : Josef Raabe, 2018, 203 s. ISBN 978-80-8140-355-2.

- TÓTHOVÁ, Marta: Interpretácia práva a právny jazyk. In: Dny práva - 2010 - Days of Law : sborník přispěvki̊ : 4.ročník mezinárodní konference. Brno : Masarykova univerzita, 2010. (s. 2993-3003). ISBN 978-80-210-5305-2.

\section{Summary: The Quality of Legislator's Expression in the Context of Legal Liability according to the Act of Municipal Establishment}

Normative diction $\S 27 \mathrm{~b}$ the Act No. 369/1990 Coll. of municipial establishment shows several shortcomings and ambiguities. The first shortcoming is the use of the same names for different types of sources of law. The Act uses the designation "regulation" in relation to a regulation of the Government of the Slovak Republic and a generally binding regulation of a municipality. De lege ferenda, it would be necessary to distinguish consistently between the two types of sources of law. It is uncertain whether a breach of the obligation to maintain cleanliness in the municipality may establish a single-action concurrence of administrative torts under $\S 27 \mathrm{~b}$ the Act No. 369/1990 Coll. of municipial establishment. The exclusion of single-acting concurrency is only problematicly described by theory. This should be adapted by the normative text. The ratio of repeated breaches of obligations and breaches of several obligations 
according to $\S 27 \mathrm{~b}$ the Act No. 369/1990 Coll. of municipial establishment. It is not clear whether the aggravation of "repeated breaches" is intended to imply recidivism or overlap. By analogical application of the criminal code, concurrence can be considered. This issue should also be regulated more clearly by the law.

Mgr. Lukáš Tomaš Univerzita Pavla Jozefa Šafárika v Košiciach Právnická fakulta, Ústav teórie práva Gustava Radbrucha

Kováčska 26

04075 Košice

Slovenská republika

lukas.tomas@student.upjs.sk 